\title{
GAMBARAN PERILAKU KELUARGA DALAM MANAJEMEN HALUSINASI PADA ANGGOTA KELUARGA DENGAN SKIZOFRENIA DI WILAYAH KERJA PUSKESMAS IMOGIRI II
}

\author{
Densa Anggiviani Prity ${ }^{1}$, Tri Prabowo ${ }^{2}$, Sarka Ade Susana ${ }^{3}$ \\ ${ }^{1}$ Mahasiswa Jurusan Keperawatan ${ }^{2,3}$ Dosen Jurusan Keperawatan \\ Jurusan Keperawatan Poltekkes Kemenkes Yogyakarta, Jl. Tatabumi No. 3 Banyuraden, \\ Gamping, Sleman, Yogyakarta 55293 \\ Email: densa.anggiviani@gmail.com*
}

\begin{abstract}
Schizophrenia is a disorder that occurs in the human brain that causes a very dramatic behavior change. Positive symptoms of schizophrenia are hallucinations. Based on a report from Imogiri II Public Health Center in 2016 there were 218 people with mental disorders in which $70 \%$ experienced hallucinations. Family is the closest person and has an active role in providing direct care to people with schizophrenia. The purpose of this study is to know the description of family behavior in hallucination management in family members with schizophrenia in the working area of Imogiri II Community Health Center. This research uses descriptive research type as research design. The sampling technique used is simple random sampling with 78 respondents. The research instrument used is questionnaire. The result of the research showed that 78 respondents in the range of age 41 60 years old $(51.28 \%)$, the last educated is elementary $(46.15 \%)$, most of the respondent is jobless $(51.28 \%)$, respondent is parent of schizophrenia family (29.49\%), and had take care for more than of 10 years $(33.33 \%)$, respondents knowledge level mostly good (57.69\%) and respondent attitude mostly positive (58.97\%). The description of behavior in hallucination management in family members with schizophrenia is in good category $(57.69 \%)$. The results of this study recommend the need for motivation and support from health services to maintain good family behavior in hallucination management so that there is no risk of violent behavior and recurrence in schizophrenic patients with hallucinations.
\end{abstract}

Keywords: hallucinations management, family behavior, schizophrenia

\begin{abstract}
ABSTRAK
Skizofrenia merupakan sebuah gangguan yang terjadi pada otak manusia yang menyebabkan terjadinya perubahan perilaku yang sangat dramatis. Gejala positif dari skizofrenia berupa halusinasi. Berdasarkan laporan dari Puskesmas Imogiri II tahun 2016 terdapat 218 orang dengan gangguan jiwa dimana $70 \%$ mengalami halusinasi. Keluarga merupakan orang terdekat dan memiliki peran aktif dalam memberikan perawatan langsung pada penderita skizofrenia. Tujuan dari penelitian ini adalah diketahuinya gambaran perilaku keluarga dalam manajemen halusinasi pada anggota keluarga dengan skizofrenia di wilayah kerja Puskesmas Imogiri II. Penelitian ini menggunakan jenis penelitian deskriptif sebagai desain penelitian. Teknik sampling yang digunakan yaitu dengan simple random sampling dengan jumlah 78 responden. Instrumen penelitian yang digunakan yaitu kuesioner. Hasil penelitian menunjukkan bahwa dari 78 responden didapatkan paling banyak dalam rentang umur 41-60 tahun (51,28\%), berpendidikan terakhir paling banyak SD (46,15\%), responden paling banyak tidak bekerja $(51,28 \%)$, responden sebagian besar adalah orangtua penderita skizofrenia $(29,49 \%)$, lama merawat sebagian besar lebih dari 10 tahun $(33,33 \%)$, tingkat pengetahuan responden sebagian besar baik $(57,69 \%)$ dan sikap responden sebagian besar positif $(58,97 \%)$. Gambaran perilaku dalam manajemen halusinasi pada anggota keluarga dengan skizofrenia termasuk dalam kategori baik (57,69\%). Hasil dari penelitian ini menyarankan perlunya motivasi dan dukungan dari pelayanan kesehatan untuk mempertahankan perilaku baik keluarga dalam manajemen halusinasi sehingga tidak terjadi resiko perilaku kekerasan dan kekambuhan berulang pada penderita skizofrenia dengan halusinasi.
\end{abstract}

Kata kunci: manajemen halusinasi, perilaku keluarga, skizofrenia 


\section{A. PENDAHULUAN}

Kesehatan jiwa adalah suatu kondisi sehat emosional, psikologis dan sosial yang terlihat dari hubungan interpersonal yang memuaskan, perilaku dan koping yang efektif, konsep diri yang positif dan kestabilan emosional ${ }^{1}$. Salah satu gangguan jiwa berat dari kesehatan jiwa sendiri dapat berupa skizofrenia. Skizofrenia merupakan sebuah gangguan yang terjadi pada otak manusia yang menyebabkan terjadinya perubahan perilaku yang sangat dramatis ${ }^{2}$.

Prevalensi penderita gangguan jiwa di Indonesia dilihat dari data Riset Kesehatan Dasar (Riskesdas) tahun 2013 terdapat 1,72 per seribu atau sekitar 400 ribu orang mengalami gangguan jiwa berat. Provinsi Daerah Istimewa Yogyakarta merupakan salah satu prevalensi tertinggi diantara provinsi yang lain di Indonesia yaitu mencapai 2,7 per mil $^{3}$. Puskesmas Imogiri II merupakan salah satu puskesmas yang berada di kabupaten Bantul yang sudah memiliki program kesehatan jiwa masyarakat juga mengalami peningkatan angka orang dengan gangguan jiwa dengan jumlah penderita skizofrenia pada tahun 2015 sebanyak 207 orang dan pada tahun 2016 sebanyak 218 orang, sedangkan 153 orang (70\%) penderita skizofrenia mengalami halusinasi dimana hanya 80 orang penderita skizofrenia dengan halusinasi yang rutin melakukan kontrol.

Meskipun setiap 6 bulan sekali puskesmas sudah mengadakan family gathering untuk keluarga yang memiliki anggota keluarga skizofrenia tidak menutup kemungkinan ada sebagian keluarga yang masih memiliki perilaku kurang baik. Berdasarkan studi pendahuluan dapat terlihat bahwa 4 keluarga belum melakukan tindakan yang benar tentang cara memanajemen halusinasi.

Perilaku keluarga dalam manajemen halusinasi sangat penting agar keluarga dapat menangani secara dini jika terdapat tanda dan gejala halusinasi sehingga dapat mencegah terjadinya keparahan halusinasi yang akan menyebabkan penderita dapat membahayakan diri sendiri atau orang lain karena timbulnya perilaku kekerasan, selain itu perilaku memanajemen halusinasi juga penting dilakukan untuk mencegah kekambuhan berulang.

\section{B. METODE PENELITIAN}

Penelitian ini merupakan jenis penelitian deskriptif dengan desain survei. Sampel penelitian ini diambil menggunakan teknik simple random sampling. Sampel diambil dari anggota keluarga yang memiliki anggota keluarga skizofrenia di 
Puskesmas Imogiri II yang memenuhi kriteria inklusi yang dimulai dari 4 Maret- 4 April 2017. Jumlah sampel sebanyak 78 responden.

\section{HASIL PENELITIAN}

1. Karakteristik responden

\begin{tabular}{|c|c|c|c|}
\hline No & Karakteristik & Frekuensi (f) & Prosentase $(\%)$ \\
\hline \multirow[t]{5}{*}{1.} & Urmur: & & \\
\hline & $13-20$ & 5 & 6,41 \\
\hline & $21-40$ & 24 & 30,77 \\
\hline & $41-60$ & 40 & 51,28 \\
\hline & $>60$ & 9 & 11,54 \\
\hline \multirow[t]{6}{*}{2.} & Pendidikan: & & \\
\hline & Tidak Sekolah & 2 & 2,56 \\
\hline & SD & 36 & 46,15 \\
\hline & SMP & 23 & 29,49 \\
\hline & SNAA & 16 & 20,51 \\
\hline & S1 & 1 & 1,28 \\
\hline \multirow[t]{6}{*}{3.} & Pekerjaan: & & \\
\hline & Tidak Bekerja & 40 & 51,28 \\
\hline & Tani/Bunuh & 25 & 32,06 \\
\hline & Wiraswasta & 10 & 12,82 \\
\hline & Dagang & 2 & 2,56 \\
\hline & Nelayan & 1 & 1,28 \\
\hline \multirow[t]{8}{*}{4.} & Hubungan dengan penderita: & & \\
\hline & Orangtua & 23 & 29,49 \\
\hline & Anak & 19 & 24,36 \\
\hline & Istri & 7 & 8,97 \\
\hline & Adik & 10 & 12,82 \\
\hline & Kakak & 4 & 5,13 \\
\hline & Cucu & 4 & 5,13 \\
\hline & Sepupu & 11 & 14,10 \\
\hline \multirow[t]{7}{*}{5.} & Lama meravvat: & & \\
\hline & 1 Tahum & 3 & 3,85 \\
\hline & 3 Tahum & 19 & 24,36 \\
\hline & 5 Tahum & 8 & 10,26 \\
\hline & 7 Tahum & 3 & 3,85 \\
\hline & 10 Tahum & 19 & 24,36 \\
\hline & $>10$ Takun & 26 & 33,33 \\
\hline
\end{tabular}

Tabel 3 menunjukkan bahwa paling banyak responden berumur 41-60 tahun yaitu sebanyak 40 responden $(51,28 \%)$. Sebanyak 36 responden $(46,15 \%)$ berpendidikan terakhir SMP. Sebanyak 40 (51,28\%) responden tidak bekerja. Sebanyak 23 responden $(29,49 \%)$ merupakan orangtua dari penderita skizofrenia. Sebanyak 26 responden $(33,33 \%)$ sudah lebih dari 10 tahun merawat penderita skizofrenia. 
Tabel 4. Distribusi Frekuensi Responden Berdasarkan Perilaku di Wilayah Kerja Puskesmas Imogin II ( $\mathrm{n}=78$ )

\begin{tabular}{clcc}
\hline No & Perilaku & Frekuensi (f) & Prosentase (\%) \\
\hline 1. & Baik & 48 & 61,54 \\
2. & Cukup & 30 & 38,46 \\
3. & Sedang & 0 & 0 \\
\hline & Jumlah & 78 & 100 \\
\hline
\end{tabular}

Tabel 4 dapat dilihat bahwa perilaku tentang manajemen halusinasi adalah 48 responden $(61,54 \%)$ bernilai baik, ada 30 responden $(38,46 \%)$ bernilai cukup, dan 0 responden $(0 \%)$ bernilai kurang.

\section{Tabel 5. Distribusi Frekuensi Responden dengan Anggota Keluarga Skizo frenia Rutin Kontrol Berdasarkan Perilaku di Wilayah Kerja Puskesmas Imogin II ( $\mathrm{n}=39$ )}

\begin{tabular}{clcc}
\hline No & Perilaku & Frekuensi (f) & Prosentase (\%) \\
\hline 1. & Baik & 33 & 84,62 \\
2. & Cukup & 6 & 15,38 \\
3. & Sedang & 0 & 0 \\
\hline & Jumlah & 39 & 100 \\
\hline
\end{tabular}

Tabel 5 dapat dilihat bahwa perilaku tentang manajemen halusinasi adalah 33 responden $(84,62 \%)$ bernilai baik, ada 6 responden $(15,38 \%)$ bernilai cukup, dan 0 responden $(0 \%)$ bernilai kurang.

Tabel 6. Distribusi Frekuensi Responden dengan Anggota Keluarga Skizo frenia Tidak Rutin Kontrol Berdasarkan Perilaku di Wilayah Kerja Puskesmas Imogin II ( $\mathrm{n}=39)$

\begin{tabular}{clcc}
\hline No & Perilaku & Frekuensi (f) & Prosentase (\%) \\
\hline 1. & Baik & 15 & 38,46 \\
2. & Cukup & 24 & 61,54 \\
3. & Sedang & 0 & 0 \\
\hline & Jumlah & 39 & 100 \\
\hline
\end{tabular}


Tabel 6 dapat dilihat bahwa perilaku dalam manajemen halusinasi adalah 15 responden $(38,46 \%)$ bernilai baik, ada 24 responden $(61,54 \%)$ bernilai cukup, dan 0 responden $(0 \%)$ bernilai kurang.

\section{Tabel 7. Distribusi Frekuensi RespondenBerdasarkan Tingkat Pengetahuan di Wilayah Kerja Puskesmas Imogiri II $(\mathrm{n}=78)$}

\begin{tabular}{clcc}
\hline No & Tingkat Pengetahuan & Frekuensi (f) & Prosentase (\%) \\
\hline 1. & Baik & 45 & 57,69 \\
2. & Cukup & 27 & 34,62 \\
3. Sedang & 6 & 7,69 \\
\hline & Jumlah & 78 & 100 \\
\hline
\end{tabular}

Tabel 7 dapat dilihat bahwa tingkat pengetahuan dalam manajemen halusinasi adalah 45 responden $(57,69 \%)$ bernilai baik, ada 27 responden $(34,62 \%)$ bernilai cukup, dan 6 responden $(7,69 \%)$ bernilai kurang.

Tabel 8. Distribusi Frekuensi Tingkat Pengetahuan Responden berdasarkanumur, pendidikan, pekerjaan, danlama merawat di Wilayah Kerja Puskesmas Imogin II ( $n=78$ )

\begin{tabular}{|c|c|c|c|c|c|c|c|c|c|}
\hline \multirow{3}{*}{ No } & \multirow{3}{*}{ Karakteristik } & \multicolumn{6}{|c|}{ Tingkat Pengetahuan } & \multirow{2}{*}{\multicolumn{2}{|c|}{ Total }} \\
\hline & & \multicolumn{2}{|c|}{ Baik } & \multicolumn{2}{|c|}{ Cukup } & \multicolumn{2}{|c|}{ Kurang } & & \\
\hline & & $\mathrm{f}$ & $\%$ & $\mathrm{f}$ & $\%$ & $f$ & $\%$ & f & $\%$ \\
\hline \multirow[t]{5}{*}{1.} & Umur & & & & & & & & \\
\hline & a. 13-20 tahum & 0 & 0 & 5 & 6,41 & 0 & 0 & 5 & 6,41 \\
\hline & b. $21-40$ tahum & 15 & 19,23 & 6 & 7,69 & 3 & 3,85 & 24 & 30,77 \\
\hline & c. 41-60 tahum & 27 & 34,62 & 11 & 14,10 & 2 & 2,56 & 40 & 51,28 \\
\hline & d. $>60$ tahun & 3 & 3,85 & 5 & 6,41 & 1 & 1,28 & 9 & 11,54 \\
\hline
\end{tabular}

\begin{tabular}{lcccccccc}
\hline 2. & Pendidikan & & & & & & & \\
a. Tidak sekolah & 0 & 0 & 0 & 0 & 2 & 2,56 & 2 & 2,56 \\
b.SD & 19 & 24,36 & 16 & 20,51 & 1 & 1,28 & 36 & 46,15 \\
c. SMP & 14 & 17,95 & 8 & 10,26 & 1 & 1,28 & 23 & 29,49 \\
d.SMA & 12 & 15,38 & 2 & 2,56 & 2 & 2,56 & 16 & 20,51 \\
e. S1 & 0 & 0 & 1 & 1,28 & 0 & 0 & 1 & 1,28 \\
& & & & & & & & \\
\hline 3. Pekerjaan & & & & & & & & \\
a. Tidak Bekerja & 25 & 32,05 & 11 & 14,10 & 4 & 5,13 & 40 & 51,28 \\
b. Tani/ Buruh & 13 & 16,67 & 10 & 12,82 & 2 & 2,56 & 25 & 32,05 \\
c. Wiraswasta & 7 & 8,97 & 3 & 3,85 & 0 & 0 & 10 & 12,82 \\
d. Dagang & 0 & 0 & 2 & 2,56 & 0 & 0 & 2 & 2,56 \\
e. Nelayan & 0 & 0 & 1 & 1,28 & 0 & 0 & 1 & 1,28 \\
\hline LamaMerawat & & & & & & & & \\
a.1 tahun & 1 & 1,28 & 2 & 2,56 & 0 & 0 & 3 & 3,85 \\
b.3 tahun & 12 & 15,38 & 5 & 6,41 & 2 & 2,56 & 19 & 24,36 \\
c. 5 tahun & 3 & 3,85 & 4 & 5,13 & 1 & 1,28 & 8 & 10,26 \\
d. 7 tahun & 3 & 3,85 & 0 & 0 & 0 & 0 & 3 & 3,85 \\
e. 10 tahun & 11 & 14,10 & 7 & 8,97 & 1 & 1,28 & 19 & 24,36 \\
f. $>10$ tahun & 15 & 19,23 & 9 & 11,54 & 2 & 2,56 & 26 & 33,33 \\
\hline
\end{tabular}


Tabel 8 dapat dilihat bahwa tingkat pengetahuan dalam mengelola halusinasi sebagian besar baik adalah pada responden pada rentang umur 41-60 tahun sebanyak 27 responden $(34,62 \%)$, berpendidikan terakhir SD sebanyak 19 responden $(24,36 \%)$, tidak bekerja sebanyak 25 responden $(32,05 \%)$ dan responden dengan lama merawat lebih dari 10 tahun sebanyak 15 responden $(19,23 \%)$.

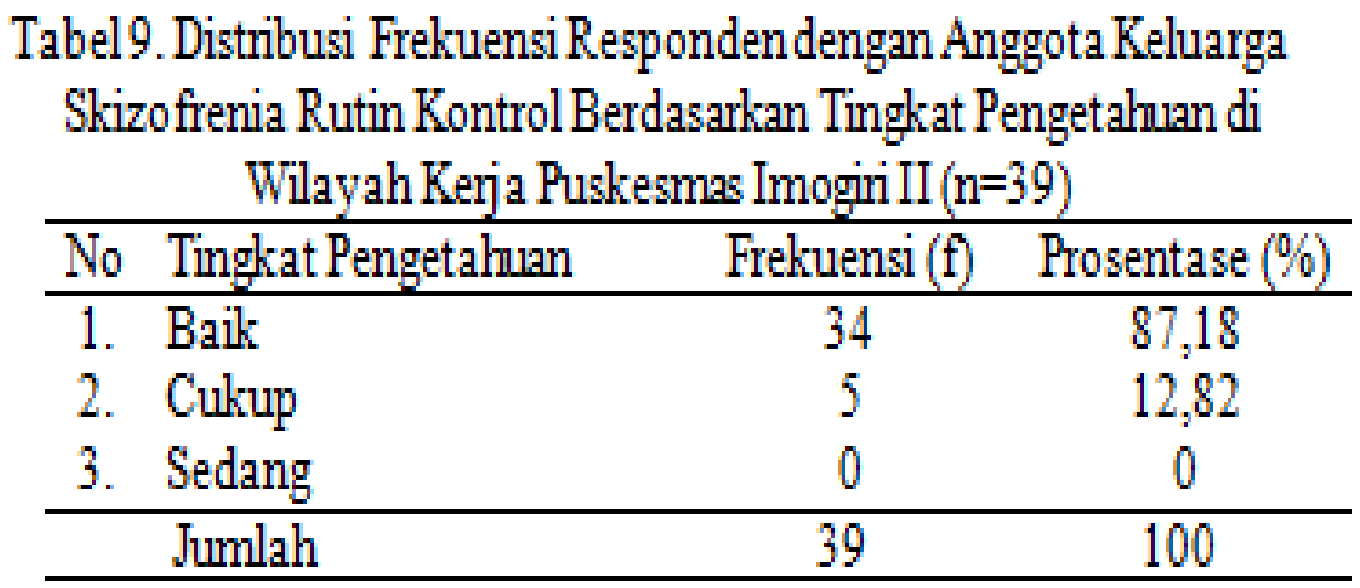

Tabel 9 dapat dilihat bahwa tingkat pengetahuan tentang manajemen halusinasi adalah 34 responden $(87,18 \%)$ bernilai baik, ada 5 responden $(12,82 \%)$ bernilai cukup, dan 0 responden $(0 \%)$ bernilai kurang.

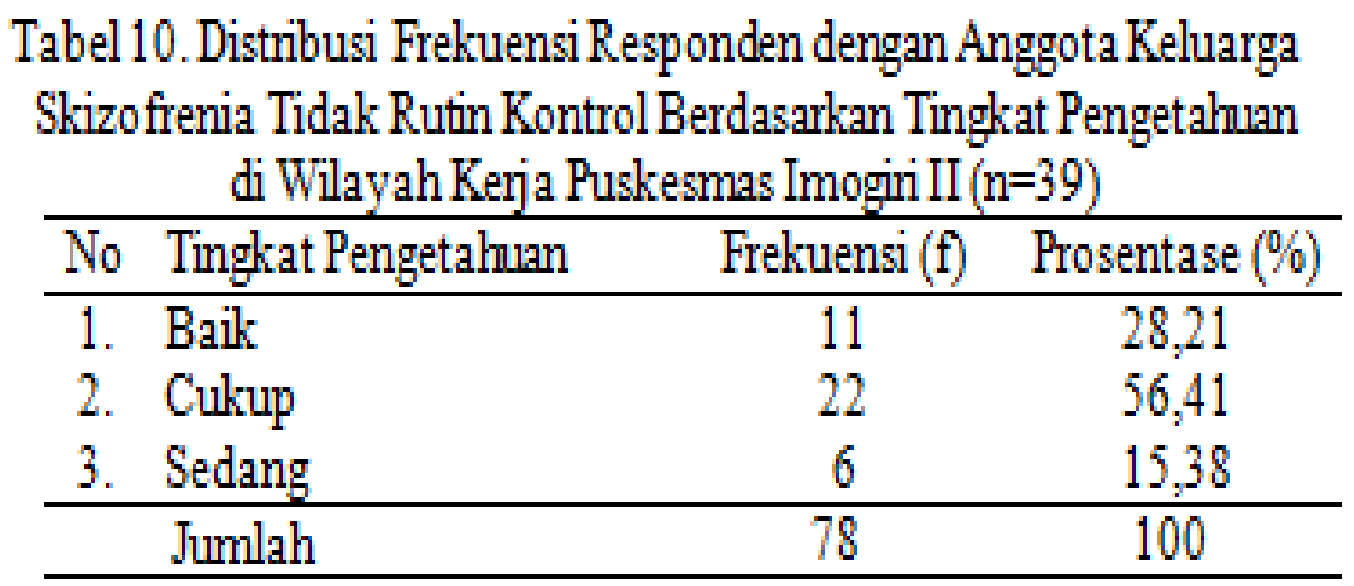

Tabel 10 dapat dilihat bahwa tingkat pengetahuan tentang manajemen halusinasi adalah 22 responden $(56,41 \%)$ bernilai cukup, ada 11 responden $(28,21 \%)$ bernilai baik, dan 6 responden $(15,38 \%)$ bernilai kurang. 
Tabel 11.Distribusi Frekuensi Responden Berdasarkan Sikap di Wilayah Kerja Puskesmas Imogin II $(\mathrm{n}=78)$

\begin{tabular}{clcc}
\hline No & Sikap & Frekuensi $(\mathrm{f})$ & Prosentase (\%) \\
\hline 1. & Positif & 46 & 58,97 \\
2. & Negatif & 32 & 41,03 \\
\hline & Jumlah & 78 & 100 \\
\hline
\end{tabular}

Tabel 11 dapat dilihat bahwa sikap responden tentang manajemen halusinasi adalah 46 responden $(58,97 \%)$ bernilai positif dan 32 responden $(41,03 \%)$ bernilai negatif.

Tabel 12. Distribusi Frekuensi Sikap Respondenberdasarkan pendidikan, hubungandengan responden, dan lama merawat di Wilayah Kerja Puskesmas Imogini II $(\mathrm{n}=78)$

\begin{tabular}{llllllll}
\hline No & Karakteristik & \multicolumn{3}{c}{ Sikap } & & \multirow{2}{*}{ Total } \\
\cline { 2 - 4 } & & \multicolumn{2}{c}{ Positif } & Negatif & & \\
\cline { 2 - 5 } & f & $\%$ & f & $\%$ & & f & $\%$ \\
\hline
\end{tabular}

\begin{tabular}{|c|c|c|c|c|c|c|c|}
\hline \multicolumn{8}{|c|}{ 1. Pendidikan } \\
\hline & a. Tidak sekolah & 1 & 1,28 & 1 & 1,28 & 2 & 2,56 \\
\hline & b. SD & 21 & 26,92 & 15 & 19,23 & 36 & 46,15 \\
\hline & c. SMP & 15 & 19,23 & 8 & 10,26 & 23 & 29,49 \\
\hline & d. SMA & 8 & 10,26 & 8 & 10,26 & 16 & 20,51 \\
\hline & e. S1 & 1 & & 0 & 0 & 1 & \\
\hline \multirow[t]{8}{*}{2 . } & Hubungan & & & & & & \\
\hline & a. Ibu/Ayah & 15 & 19,23 & 8 & 10,26 & 23 & 29,49 \\
\hline & b. Anak & 11 & 14,10 & 8 & 10,26 & 19 & 24,36 \\
\hline & c. Istri & 5 & 6,41 & 2 & 2,56 & 7 & 8,97 \\
\hline & d. Adik & 6 & 7,63 & 4 & 5,13 & 10 & 12,8 \\
\hline & e. Kakak & 4 & 5,13 & 0 & 0 & 4 & 5,13 \\
\hline & f. Cucu & 1 & 1,28 & 3 & 3,85 & 4 & 5,13 \\
\hline & g. Sepupu & 4 & 5,13 & 7 & 8,97 & 11 & 14,10 \\
\hline \multirow[t]{7}{*}{3.} & Lam a Merawat & & & & & & \\
\hline & a. 1 tahun & 2 & 2,56 & 1 & 1,28 & 3 & 3,85 \\
\hline & b. 3 tahun & 7 & 8,97 & 12 & 15,39 & 19 & 24,36 \\
\hline & c. 5 tahun & 6 & 7,63 & 2 & 2,56 & 8 & 10,26 \\
\hline & d. 7 tahun & 2 & 2,56 & 1 & 1,28 & 3 & 3,85 \\
\hline & e. 10 tahun & 12 & 15,39 & 7 & 8,97 & 19 & 24,36 \\
\hline & f. $>10$ tahun & 17 & 21,79 & 9 & 11,54 & 26 & 33,33 \\
\hline
\end{tabular}


Data yang telah disajikan pada tabel 12. maka dapat dilihat bahwa sikap responden dalam mengelola halusinasi sebagian besar positif pada responden dengan pendidikan terakhir SD sebanyak 21 responden $(26,92 \%)$, responden yang memiliki hubungan dengan penderita skizofrenia sebagai orangtua sebanyak 15 responden $(19,23 \%)$ dan responden dengan lama merawat lebih dari 10 tahun sebanyak 17 responden $(21,79 \%)$.

\section{Tabel 13. Distribusi Frekuensi Responden dengan Anggota Keluarga Skizo frenia Rutin Kontrol Berdasarkan Sikap di Wilayah Keja Puskesmas Imogin II ( $\mathrm{n}=39)$}

\begin{tabular}{clcc}
\hline No & Sikap & Frekuensi (f) & Prosentase (\%) \\
\hline 1. & Positif & 22 & 56,41 \\
2. & Negatif & 17 & 43,59 \\
\hline & Jumlah & 78 & 100 \\
\hline
\end{tabular}

Tabel 13 dapat dilihat bahwa tingkat pengetahuan tentang manajemen halusinasi adalah 22 responden $(56,41 \%)$ bernilai positif dan 17 responden $(43,59 \%)$ bernilai negatif.

$\begin{aligned} & \text { Tabel 14. Distribusi Frekuensi Responden dengan Anggota Keluarga } \\
& \text { Skizofrenia Tidak Rutin Kontrol Berdasarkan Sikap }\end{aligned}$
\begin{tabular}{cccc} 
di Wilayah Kerja Puskesmas Imogin II(n=39) \\
\hline No & Sikap & Frekuensi (f) & Prosentase (\%) \\
\hline 1. & Positif & 24 & 61,54 \\
2. & Negatif & 15 & 38,46 \\
\hline & Jumlah & 78 & 100 \\
\hline
\end{tabular}

Tabel 14 dapat dilihat bahwa sikap tentang manajemen halusinasi adalah 24 responden $(61,54 \%)$ bernilai positif dan 15 responden $(38,46 \%)$ bernilai negatif.

\section{PEMBAHASAN}

1. Karakteristik responden

Karakteristik responden pada penelitian ini dilihat pada pada tabel 3 . menunjukkan bahwa sebagian besar responden berada di rentang usia 41-60 tahun $(51,28 \%)$. Data pada tabel 3. menunjukkan bahwa sebagian besar responden 
berpendidikan terakhir SD $(46,15)$ dan sebagian besar responden tidak bekerja atau ibu rumah tangga (51,28\%). Data pada tabel 3. menunjukkan bahwa sebagian besar responden memiliki hubungan sebagai orangtua dari anggota keluarga dengan skizofrenia $(29,49)$ dan sebagian besar responden telah merawat anggota keluarga dengan skizofrenia selama lebih dari 10 tahun $(33,33 \%)$.

2. Perilaku responden dalam manajemen halusinasi

Hasil penelitian menunjukkan bahwa sebagian besar responden dalam mengelola halusinasi memiliki perilaku baik $(61,54 \%)$. Hal tersebut dikarenakan sebagian besar responden memiliki tingkat pengetahuan yang baik dalam mengelola halusinasi dan sebagian besar responden memiliki sikap yang baik dalam mengelola halusinasi.

Faktor pembentuk perilaku dibagi menjadi 3 yaitu faktor pendorong antara lain pengetahuan dan sikap responden yang baik. Faktor pemungkin yaitu fasilitas dari puskesmas yang sudah memiliki program kesehatan jiwa masyarakat seperti diadakannya family gathering setiap 6 bulan sekali bagi keluarga yang memiliki anggota keluarga dengan skizofrenia dan pendidikan kesehatan mengenai skizofrenia. Faktor penguat yang memperkuat terjadinya perilaku baik seperti kepedulian tenaga kesehatan terhadap keluarga dengan anggota keluarga skizofrenia ${ }^{4}$.

Data pada tabel 5. menunjukkan bahwa perilaku responden dengan anggota keluaraga skizofrenia yang melakukan kontrol rutin sebagian besar memiliki perilaku baik $(84,62 \%)$ sedangkan data pada tabel 6. menunjukkan bahwa responden dengan anggota keluarga skizofrenia yang tidak kontrol rutin sebagian besar memiliki perilaku yang cukup (61,54\%). Hasil dari penelitian ini menunjukkan bahwa perilaku keluarga yang rutin lebih baik daripada keluarga yang tidak kontrol rutin, hal tersebut dapat disebabkan karena pada keluarga yang rutin melakukan kontrol lebih banyak terpapar informasi dari tenaga kesehatan, selain itu sebagian besar keluarga yang rutin kontrol selalu konsisten terhadap keluarga yang mendampingi anggota keluarga dengan skizofrenia. Selain itu peran keluarga adalah sebagai support system sehingga dapat mengurangi tingkat kekambuhan, meningkatkan pemulihan, dan meningkatkan kesejahteraan keluarga ${ }^{5}$. 
3. Perilaku berdasarkan tingkat pengetahuan responden

Hasil penelitian menunjukkan bahwa sebagian besar responden memiliki tingkat pengetahuan dalam mengelola halusinasi adalah baik $(57,69 \%)$.

Terdapat banyak faktor yang terkait dengan tingkat pengetahuan seseorang diantaranya adalah umur, pendidikan, pekerjaan, dan lama merawat. Dapat dilihat pada tabel 8. Bahwa sebagian besar responden yang memiliki pengetahuan baik ada di rentang umur 41-60 tahun, berpendidikan SD, tidak bekerja dan telah merawat lebih dari 10 tahun. Selain data diatas terdapat hal lain yang dapat mempengaruhi tingkat pengetahuan responden yaitu kerutinan kontrol anggota keluarga dengan skizofrenia ke pelayanan kesehatan ${ }^{6}$.

Data pada tabel 5. menunjukkan bahwa responden dengan anggota keluarga skizofrenia yang rutin melakukan kontrol memiliki tingkat pengetahuan yang lebih baik daripada responden pada tabel 6. dengan anggota keluarga skizofrenia yang tidak rutin kontrol. Hal tersebut dapat terjadi karena keluarga yang rutin kontrol akan lebih banyak terpapar informasi dan mendapat penyuluhan dari tenaga kesehatan saat mendampingi keluarganya di unit pelayanan kesehatan.

4. Perilaku berdasarkan sikap responden

Hasil penelitian menunjukkan bahwa sebagian besar responden memiliki sikap positif $(58,97 \%)$. Sebagian besar keluarga juga mengerti bahwa anggota keluarga dengan skizofrenia harus dikelola halusinasinya dengan sikap yang positif. Sebagian besar keluarga juga tidak membiarkan anggota keluarga dengan skizofrenia untuk tinggal secara terpisah atau dikurung. Sikap yang positif dapat dipengaruhi oleh pengetahuan responden yang baik pula ${ }^{7}$.

Faktor-faktor yang berkaitan dengan sikap. diantaranya adalah pendidikan, hubungan dengan responden dan lama merawat. Dapat dilihat pada tabel 12 . Bahwa sebagian besar responden yang memiliki sikap positif berpendidikan terakhir SD, sebagian besar responden merupakan orangtua dari anggota keluarga dengan skizofrenia dan telah merawat lebih dari 10 tahun.

Data pada tabel 14. menunjukkan bahwa responden dengan anggota keluarga skizofrenia yang jarang melakukan kontrol memiliki sikap positif lebih banyak daripada responden dengan anggota keluarga skizofrenia yang rutin melakukan kontrol pada tabel 13. Hal tersebut dapat terjadi karena faktor-faktor 
seperti lama merawat dan hubungan responden dengan anggota keluarga dengan skizofrenia.

\section{E. KESIMPULAN DAN SARAN}

Karakteristik responden sebagian besar dalam rentang umur 41-60 tahun. Sebagian besar pendidikan terakhir responden yaitu SD dan tidak bekerja. Mayoritas responden adalah orangtua dari anggota keluarga dengan skizofrenia dan sebagian besar telah merawat anggota keluarga dengan skizofrenia selama lebih dari 10 tahun. Perilaku keluarga dalam memanajemen halusinasi pada anggota keluarga dengan skizofrenia sebagian besar baik. Perilaku keluarga yang rutin kontrol dalam manajemen halusinasi sebagian besar baik dan perilaku keluarga yang tidak rutin kontrol dalam manajemen halusinasi sebagian besar adalah cukup. Perilaku keluarga berdasarkan pengetahuan dalam manajemen halusinasi sebagian besar adalah baik. Pengetahuan keluarga yang rutin kontrol mayoritas baik dan keluaraga yang tidak rutin kontrol mayoritas cukup. Perilaku keluarga berdasarkan sikap dalam manajemen halusinasi sebagian besar baik. Sikap keluarga yang rutin kontrol sebagian besar adalah baik dan sikap keluarga yang tidak tidak rutin kontrol sebagian besar baik.

\section{DAFTAR PUSTAKA}

1. Videbeck. (2008). Buku Ajar Keperawatan Jiwa alih bahasa Komalasari R. Jakarta: EGC

2. Yosep, I. (2009). Keperawatan Jiwa. Bandung: Refika Aditama

3. Sugianto, dkk. (2013). Riskesdas dalam Angka Provinsi Daerah Istimewa Yogyakarta Tahun 2013. Jakarta: Lembaga Penerbitan Badan Litbangkes

4. Lestari, T. (2015). Kumpulan Teori untuk Kajian Pustaka Penelitian Kesehatan. Yogyakarta: Nuha Medika

5. Stuart, G.W. (2016). Prinsip dan Praktik Kperawatan Jiwa Stuart, $1^{\text {st }}$ Indonesian Edition. Singapura: Elsevier Inc. 
6. Hayani, L., Elita, E., Hasanah, O., 2014. Gambaran Pengetahuan Keluarga Tentang Cara merawat Paien Halusinasi di Rumah. Jurnal Online Mahasiswa (JOM) Bidang Ilmu Keperawatan. Vol 1, No. 1

7. Muntiaroh, Hidayati, E., Meikawati, W. 2013. Gambaran Tingkat Pengetahuan Tentang Skizofrenia dan Dukungan Keluarga Pada Klien Skizofrenia di Rumah Sakit Jiwa Daerah Dr Amino Gondohutomo Semarang. Prosiding Seminar Nasional 2013. 